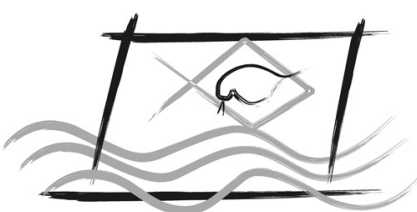

ECOTOX - BRASIL

\title{
Effect of probiotics, antibiotics and herbal extracts against fish bacterial pathogens
}

\author{
R. Pannu ${ }^{1,3} ;$ S. Dahiya ${ }^{2} ;$ V.P. Sabhlok ${ }^{2} ;$ D. Kumar ${ }^{3} ;$ V. Sarsar ${ }^{3} \&$ S.K. Gahlawat ${ }^{1}$ \\ 1 Department of Biotechnology, Ch. Devi Lal University, Sirsa-125055 Haryana India \\ 2 Department of Zoology \& Aquaculture, CCS Haryana Agricultural University, Hisar-125004 Haryana India \\ 3 Department of Biotechnology, Deenbandhu Chhotu Ram University of Science and Technology, Murthal-131039 Haryana India
}

(Received June 17, 2013; Accept November 04, 2013)

\begin{abstract}
In this study the effect of probiotic preparations and plant extract was investigated against eleven fish bacterial pathogens viz. Aeromonas hydrophila, Cellobiococcus sp., Enterobacter aerogenes, E. cloacae, Klebsiella pneumoniae, Salmonella sp., Shigella sp., Streptobacillus sp., Streptococcus sp., Pseudomonas fluorescens and Staphylococcus aureus. All these pathogens were found to be resistant for antibiotics viz. nitrofurantoin, amoxycillin, bacitracin, cephalothin, erythromycin, novobiocin, vancomycin, amphicillin, oxacillin and colistin. In vitro antagonism test of the probiotics was performed by using well diffusion method. In case of probiotic Aquapro ${ }^{\mathrm{TM}}$, effective zone of inhibition of $2.433 \mathrm{~cm}$ was observed for P. fluorescens and K. pneumoniae. The extracts of Azadirachta indica, Aloe barbadensis, Withania somnifera and Momordica charantia were studied in vitro alone as well as in combination with probiotic (Lactobacillus sporogenes). The zone of inhibition observed in mixed sample was less as compared to individual sample. Among the four plants extract, the $W$. somnifera extract was found to be the most effective and it leads to maximum inhibition $(1.1 \mathrm{~cm})$ recorded for E. aerogenes.
\end{abstract}

Keywords: Antibacterial activity, plant extract, fish disease, zone of inhibition.

\section{INTRODUCTION}

Aquaculture is the fastest growing food-producing sector in the world, with an average annual growth rate of $8.9 \%$ and practiced in a variety of agro-climatic zones ranging from tropical to temperate area (Subasinghe, 2005). It includes farming of aquatic organisms, including fish, molluscs, crustaceans and aquatic plants. The world aquaculture has grown tremendously during the last fifty years from a production of less than a million tonnes to 59.4 million tonnes. The production in aquaculture is hampered by disease caused by various fish pathogens and is constraint to the culture of many aquatic species (Bondad-Reantaso, 2005). The persistent disease problems in aquaculture necessitate the use of bacterial control agents as probiotics which can be effectively used as an alternative to antibiotics.

The common probiotics used in aquaculture belonging to genus Lactobacillus (Rollo et al., 2006), Bacillus sp.(Banerjee et al., 2007), Bifidobacterium sp., Vibrio sp. (Li et al., 2008), Saccharomyces sp. (Ahilan et al., 2004; Aubin et al., 2005; Fazeli and Takami, 2006), Enterococcus sp., Bacillus subtilis (Ghosh et al., 2008), are now used for oral bacteriotherapy in aquaculture. The initial, major, purpose of using probiotics is to maintain or re-establish a favorable relationship between friendly and pathogenic microorganisms that constitute the flora of intestinal or skin mucus of aquatic animals (Ali, 2000). Generally, probiotic strains have been isolated from indigenous and exogenous micro biota of aquatic animals. Gram-negative facultative anaerobic bacteria such as Vibrio and Pseudomonas constitute the predominant indigenous microbiota of a variety of species of marine animals (Onarheim et al, 1994). In contrast to saltwater organisms, the indigenous microbiota of freshwater animals tends to be dominated by member of the genera Aeromonas, Plesiomonas, representatives of the family Enterobacteriaceae, and obligate anaerobic bacteria of the genera Bacteroides, Fusubacterium,

*Corresponding author: Rochika Pannu; e-mail: rochika1811@gmail.com 
and Eubacterium (Sakata, 1990). The probiotics has potential for research in the culturing of fish, crustaceans, mollusks, and live food (reviewed by Verschuere et al., 2000). Apart from probiotics the marine actinomycetes has been evaluated for antagnostic activity against fish bacterial pathogens viz. Aeromonas hydrophila, A. sorbia and Edwardsiella tarda (Patil et al., 2001).

Plants have been used as traditional medicine since time immemorial to control bacterial, viral and fungal diseases. Treatment of bacterial diseases with different herbs has been safely used in organic agriculture, veterinary, human medicines and aquaculture with potent antimicrobial properties (Pandey et al., 2012). Medicinal plants as alternative agents are effective to treat infectious disease and mitigate any of side effects that are associated with synthetic antimicrobials. Plants like Azadirachta indica, Cinnmommum verum, Eupatorium odoratum, Solanum torvum, Curcuma longa, Datura metel, Aloe barbadensis, Nuphar lutea, Nymphaea alba, Gynista lydia, Phyllanthus niruri, Cynodon dactylon, Calotropis gigantean Withania somnifera, Vinca minor, Momordica charantia, Fragaria vesca have potential for being effective herbal drugs against the fish and other aquaculture pathogens (Pandey et al, 2012, Shankar Murthy and Kiran, 2013, Kannapan and Krishnamoorthy, 2013). Plant or herbal extract have minimal side effects, easily biodegradable, inexpensive and extracts can be easily prepared. Plants generally produce many secondary metabolites i.e. tannins, alkaloids and flavanoids which constitute an important source of inhibiting many pathogens. Identification and characterization of such metabolites with antimicrobial activities is very important. The usage of heavy antibiotics in aquaculture field needs to be reduced and replaced with alternative processes. Therefore, it would be beneficial to use

plant extracts as a potential and promising drug against fish pathogens as an alternative tool for disease management in aquaculture (Abutbul et al., 2005). Therefore, keeping in view the potential of antimicrobial effects of probiotics and herbal extracts in control fish bacterial pathogens the present investigation was carried out to evaluate their effect against 11 fish pathogens in vitro conditions.

\section{MATERIAL AND METHOD}

\section{Bacterial culture}

The common fish pathogenic bacteria viz. Aeromonas hydrophila, Cellobiococcus sp., Enterobactor aerogenes, Enterobactor cloacae, Klebsella pneumoniae, Pseudomonas fluorescens, Salmonella sp., Shigella sp., Streptobacillus sp., Streptococcus sp., Staphylococcus aureus were taken from the Fish Biotechnology Laboratory, Department of Zoology and Aquaculture, CCS Haryana Agricultural University, Hisar Haryana (India). All the bacterial cultures were maintained in nutrient broth and slants. Serial dilutions of all the bacterial cultures were prepared in nutrient medium and used for further studies

\section{Antibiotics, probiotics and plant extracts}

\section{Probiotics culture}

The probiotics cultures were used for studying their antagonistic behavior against the fish bacterial pathogens was; Aquapro $^{\mathrm{TM}}$ (Mixed), Exide ${ }^{\mathrm{TM}}$ (mixed), Lactobacillus sporogenes, Saccharomyces boularidia, Nitrosomonas sp., Rhodococcus sp., Aspergillus oryzae.

\section{Antibiotics}

The antibiotic discs were purchased from Hi-Media (India) and used to check antimicrobial susceptibility of bacterial pathogens; G-XVIII-minus (OD057R-1PK), G-IIIplus (OD003R-1PK), Pseudo (OD-008R-1PK) (Specific for Peseudomonas), G-II-plus (OD002R-1PK) and G-I-minus (OD005R-1PK).

\section{Plant extract}

The bioactive compounds from plants viz. Azadirachta indica, Aloe barbadensis, Withania somnifera, Momordica charantia were extracted based on the methods described by Srinivasan et al. (2009) with slight modifications. The plant was washed with $1 \% \mathrm{KMnO}_{4}(\mathrm{w} / \mathrm{v})$ to remove the epiphytes, sand and other extraneous matters. Later, the plants were dried at room temperature and pulverized using sterile pestle and mortar. One gram of the powder was mixed with $10 \mathrm{ml}$ of sterile distilled water and shaker incubated at $250 \mathrm{rpm}$ for 12 $\mathrm{h}$ at $28^{\circ} \mathrm{C}$. Then the extracts were filtered through Whatman No. 1 filter paper, the volume was minimized to $1 \%$ and then oven dried at $30^{\circ} \mathrm{C} / 2$ days. The extracts was neutralized to $\mathrm{pH}$ 7.0 with $0.1 \mathrm{~N} \mathrm{NaOH}$.

\section{In vitro antagonistic test}

Above probiotics and plant extracts were checked for their antimicrobial activity against the fish bacterial pathogens using agar well diffusion method (Gram et al., 2004). The culture medium was poisoned with pathogenic bacterial culture with concentration $1.64 \times 10^{10} \mathrm{cfu} / \mathrm{ml}$. $50 \mu \mathrm{l}$ of each probiotics and plant sample were inoculated into the bored wells inside nutrient agar medium plates. Each experiment was conducted in triplicate to observe the effective zone of inhibition. The diameter of zone was calculated by using the following formula and statistical analysis was done by oneway- ANOVA.

$$
\pi(\mathrm{R} 1-\mathrm{R} 2)(\mathrm{R} 1+\mathrm{R} 2)
$$

where R1 = Radius of zone of inhibition + Radius of test bacteria zone.

$\mathrm{R} 2=$ Radius of test bacteria zone (Well) 


\section{In vitro antimicrobial susceptibility test}

Bacterial cultures were spread on nutrient agar plates and these plates incubated at $32 \pm 1^{\circ} \mathrm{C}$ for $24 \mathrm{hrs}$. Three to four colonies were selected and transferred into $5 \mathrm{ml}$ nutrient broth medium and further incubated at $32 \pm 1^{\circ} \mathrm{C}$ for $6-8 \mathrm{~h}$. Sterile cotton swab was dipped into the bacterial suspension and pressed along the walls of tubes to remove excess of culture The entire agar surfaces were streaked with the swab. The inoculum was allowed to dry for 10-15 min with closed lid. The discs were placed inside culture plates under aseptic conditions and incubated at $32 \pm 1{ }^{\circ} \mathrm{C}$ for $24 \mathrm{~h}$. After incubation the plates were observed and the diameter of inhibition zone was measured.

\section{Statistical analysis}

To the results verified through statistical analysis was done for the inhibition zones observed for different probiotics, antibiotics and plant extract. The CD (critical difference) and $\mathrm{CV}$ (critical variance) values has been calculated and the significance of inhibition zones was analysed using one-wayAnova.

\section{RESULTS}

\section{Antibiotic sensitivity test}

The antibiotics giving zone in range $0-1.4 \mathrm{~cm}$ were resistant, $1.4-2.0 \mathrm{~cm}$ were intermediate and $2.1 \mathrm{~cm}$ or above were sensitive. Effective inhibition was observed in ciprofloxacin, norfloxacin, cephotaxime, ofloxicin and streptomycin against fish bacterial pathogens and the zone of inhibition ranges from $3.0-3.8 \mathrm{~cm}$. P. fluorescens, $S$. aureus, Salmonella sp., E. aerogenes, A. hydrophila were highly sensitive to ciprofloxacin whereas $A$. hydrophila, Cellobiococcus, Acetinobactor and Salmonella were sensitive to norfloxacin. Streptomycin was highly effective against $E$. cloacae and Cellobiococcus. Ciprofloxacin and norfloxacin has given the maximum zone of inhibition $3.8 \mathrm{~cm}$ and $3.6 \mathrm{~cm}$ against $S$. aureus and $A$. hydrophila, respectively. Nalidixicic acid, netillin, amikacin, carbenicillin and gentamicin were intermediate and the observed zone of inhibition was in range between $1.6-2.5 \mathrm{~cm}$, few bacterial species were resistant to these antibiotics. All the pathogenic species were resistant to nitrofurantoin, amoxycillin, bacitracin, cephalothin, erythromycin, novobiocin, vancomycin, ampicillin, oxacillin and colistin (Table 2a-2e, Figure2b-2c)

\section{In vitro antagonism test}

The maximum values of zone of inhibition against the fish bacterial pathogens were given by Aquapro ${ }^{\mathrm{TM}}$ among all the probiotics used. The maximum zone of inhibition observed for Aquapro ${ }^{\mathrm{TM}}$ was $2.433 \mathrm{~cm}$ against $P$. fluorescens (fig.1a) and the minimum was $1.667 \mathrm{~cm}$ against Salmonella sp. in Gram nagativeve bacteria. In case of Gram positive bacteria the maximum value observed was $2.2 \mathrm{~cm}$ and the minimum value was $1.667 \mathrm{~cm}$ against Cellobiococcus sp. and $S$. aureus. The overall statistical significance among the bacterial species was negligible due to less variation in the triplicate values. The critical difference $(\mathrm{CD})$ and critical variance (CV) for Aquapro ${ }^{\mathrm{TM}}$ were 0.148 and 4.530 respectively (Table 1a-1c, Figure1a-1b). For Exide ${ }^{\mathrm{TM}}$ maximum value of zone of inhibition observed against Gram nagative bacteria was $1.533 \mathrm{~cm}$ for Shigella sp. and in case of Gram positive bacteria $1.467 \mathrm{~cm}$ for $S$. aureus (Table 1a-1c, Figure 1e1f). The statistical significance was very less. The values of critical difference and critical variance were 0.168 and 8.419, respectively.

The maximum value of zone of inhibition observed for $L$. sporogenes in Gram negative bacteria was $1.133 \mathrm{~cm}$ against A. hydrophila and the minimum value was $0.667 \mathrm{~cm}$ against $K$. pneumoneae where as in Gram positive bacteria the maximum value observed was $1.067 \mathrm{~cm}$ against $S$. aureus and minimum value observed was $0.7 \mathrm{~cm}$ against Streptobacillus sp. (Table1a-1c, Figure1c-1d). The statistical significance was a noticeable value. The critical difference (CD) and critical variance $(\mathrm{CV})$ for $L$. sporogenes were 0.168 and 11.362 respectively. A little zone of inhibition was given by Saccharomyces boularidia against P. fluorescens, S. aureus and A. hydrophila. Aspergillus oryzae and Rhodococcus also possessed very less inhibition where as no noticeable inhibition was given by Nitrosomonas.

\section{In vitro antagonism test using herbal extract}

The antagonistic efficacy of four plants viz. Azadirachta indica, Aloe barbadensis, Withania somnifera, Momordica charantia was evaluated against fish bacterial pathogens. An effective inhibition was observed for all the four plants. In case of $A$. indica, the mean values of zone of inhibition observed against Gram negative bacteria were ranging between $0.667 \mathrm{~cm}$ (for Salmonella sp.) to $0.517 \mathrm{~cm}$ (for E.aerogenes) and against Gram positive bacteria were: $0.7 \mathrm{~cm}$ (for Cellobiococcus sp.) to $0.533 \mathrm{~cm}$ (for Streptococcus sp.). The calculated significance value was 0.076222 and critical variance was 13.093 where as the value of critical difference was non-significant.In case of A. barbadensis the mean values of zone of inhibition observed against Gram negative bacteria was $0.733 \mathrm{~cm}$ for E. aerogenes and in Gram positive pathogens, the observed values of zone of inhibition ws $0.767 \mathrm{~cm}$ against Streptococcus sp (Figure 2a2b). The statistical significance was 0.009383 where as the critical difference and critical variance values were 0.166 and 16.946 , respectively.

The mean values of the zone of inhibition observed for $W$. somnifera against the Gram negative bacteria were: $1.1 \mathrm{~cm}$ (E. aerogenes), $1.067 \mathrm{~cm}$ (A. hydrophila), $1.0 \mathrm{~cm}$ (E.cloacae), $0.933 \mathrm{~cm}$ (P. fluorescens and Salmonella sp.), $0.9 \mathrm{~cm}$ (Shigella sp.), $0.633 \mathrm{~cm}$ (Kl. pneumoneae) and against 
Gram positivebacteria were: $1.333 \mathrm{~cm}$ (Cellobiococcus sp.), $1.2 \mathrm{~cm}$ (Streptobacillus sp.), $0.967 \mathrm{~cm}$ (S. aureus), $0.867 \mathrm{~cm}$ (Streptococcus sp.). The statistical significance value calculated was 0.062574 . The values of critical difference were non-significant whereas critical variance calculated was 21.734 (Figure 2c-2d).

In case of $M$. charantia, the mean values of zone of inhibition observed against Gram negative bacteria were: $0.733 \mathrm{~cm}$ (P. fluorescens), $0.567 \mathrm{~cm}$ (K. pneumoneae), $0.533 \mathrm{~cm}$ (A. hydrophila and Shigella sp.), $0.467 \mathrm{~cm}$ (E. aerogenes), $0.450 \mathrm{~cm}$ (Salmonella sp.), $0.4 \mathrm{~cm}$ (E. cloacae) and in Gram positive fish bacterial pathogens, the observed values of zones of inhibition were: $0.8 \mathrm{~cm}$ (S. aureus), $0.650 \mathrm{~cm}$ (Cellobiococcus $\mathrm{sp}$.), $0.5 \mathrm{~cm}$ (Streptococcus sp.), $0.450 \mathrm{~cm}$ (Streptobacillus sp.) The calculated value of statistical significance was 0.000466 . The values of critical difference and critical variance were 0.16 and 16.951, respectively. When the herbal extract was used in combination with probiotic (Lactobacillus sporogenes), the zone of inhibition given by combined sample was less when compared to the zone given by individual plant samples.

Table 1a - Mean values (by one-way-ANOVA) of zone of inhibition (in cm) recorded in Aquapro ${ }^{\mathrm{TM}}$, Exide ${ }^{\mathrm{TM}}$ and Lactobacillus sporogenes against Gram negative bacterial species (data recorded as Mean $\pm \mathrm{SE}$ )

\begin{tabular}{lccc}
\hline Bacterial species & Aquapro & Exide & $\begin{array}{c}\text { Lactobacillus } \\
\text { sporogenes }\end{array}$ \\
\hline & & & \\
Aeromonas hydrophila & $1.967 \pm 0.033$ & $1.467 \pm 0.033$ & $1.133 \pm 0.067$ \\
Enterobacter aerogenes & $1.927 \pm 0.033$ & $0.867 \pm 0.088$ & $0.767 \pm 0.033$ \\
Enterobacter cloacae & $1.933 \pm 0.033$ & $1.133 \pm 0.067$ & $0.833 \pm 0.088$ \\
Klebsiella pneumoniae & $2.033 \pm 0.033$ & $0.767 \pm 0.033$ & $0.667 \pm 0.033$ \\
Pseudomonas fluorescens & $2.433 \pm 0.033$ & $1.500 \pm 0.058$ & $0.867 \pm 0.067$ \\
Salmonella sp. & $1.667 \pm 0.033$ & $0.767 \pm 0.033$ & $0.833 \pm 0.067$ \\
Shigella sp. & $1.867 \pm 0.067$ & $1.533 \pm 0.033$ & $0.900 \pm 0.058$ \\
\hline
\end{tabular}

Table 1b - Mean values (by one- way- ANOVA) of zone of inhibition (in $\mathrm{cm}$ ) recorded in Aquapro ${ }^{\mathrm{TM}}$, Exide ${ }^{\mathrm{TM}}$ and Lactobacillus sporogenes against Gram positive bacteria (data recorded as Mean \pm SE)

\begin{tabular}{lccc}
\hline Bacterial species & Aquapro $^{\mathrm{TM}}$ & Exide $^{\mathrm{TM}}$ & $\begin{array}{c}\text { Lactobacillus } \\
\text { sporogenes }\end{array}$ \\
\hline & & & \\
Cellobiococcus sp. & $1.667 \pm 0.033$ & $1.167 \pm 0.088$ & $0.767 \pm 0.033$ \\
Staphylococcus aureus & $1.667 \pm 0.188$ & $1.467 \pm 0.033$ & $1.067 \pm 0.067$ \\
Streptobacillus sp. & $2.200 \pm 0.058$ & $1.100 \pm 0.058$ & $0.700 \pm 0.000$ \\
Streptococcus sp. & $1.867 \pm 0.067$ & $1.100 \pm 0.058$ & $1.000 \pm 0.058$ \\
\hline
\end{tabular}

Table 1c - Significance, Critical Difference (CD) and Critical Variance (CV) among all eleven bacterial pathogens recorded in Aquapro ${ }^{\mathrm{TM}}$, Exide $^{\mathrm{TM}}$ and Lactobacillus sporogenes treatments.

\begin{tabular}{lccc}
\hline Character & Aquapro $^{\mathrm{TM}}$ & Exide $^{\mathrm{TM}}$ & $\begin{array}{c}\text { Lactobacillus } \\
\text { sporogenes }\end{array}$ \\
\hline Significance & 0.000000 & 0.000000 & 0.000092 \\
Critical Difference (CD) & 0.148 & 0.168 & 0.168 \\
SE(d) & 0.071 & 0.080 & 0.080 \\
SE(m) & 0.050 & 0.057 & 0.057 \\
Critical Variance (CV) & 4.530 & 8.419 & 11.362 \\
\hline
\end{tabular}
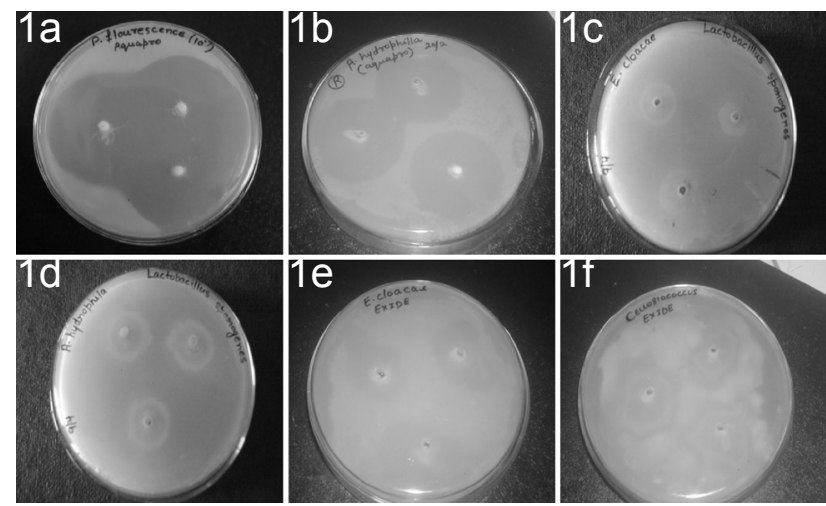

Figure 1 - Growth inhibition by Aquapro ${ }^{\mathrm{TM}}$, Exide ${ }^{\mathrm{TM}}$ and Lactobacillus sporogenes against fish bacterial pathogens. 1a Aquapro $^{\mathrm{TM}}$ against $E$.

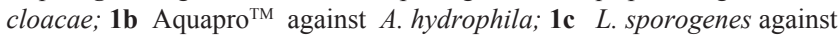
E. cloacae; 1d L. sporogenes against A. hydrophila; 1e Exide $^{\mathrm{TM}}$ against E. cloacae; 1f Exide ${ }^{\mathrm{TM}}$ against Cellobiococcus sp.
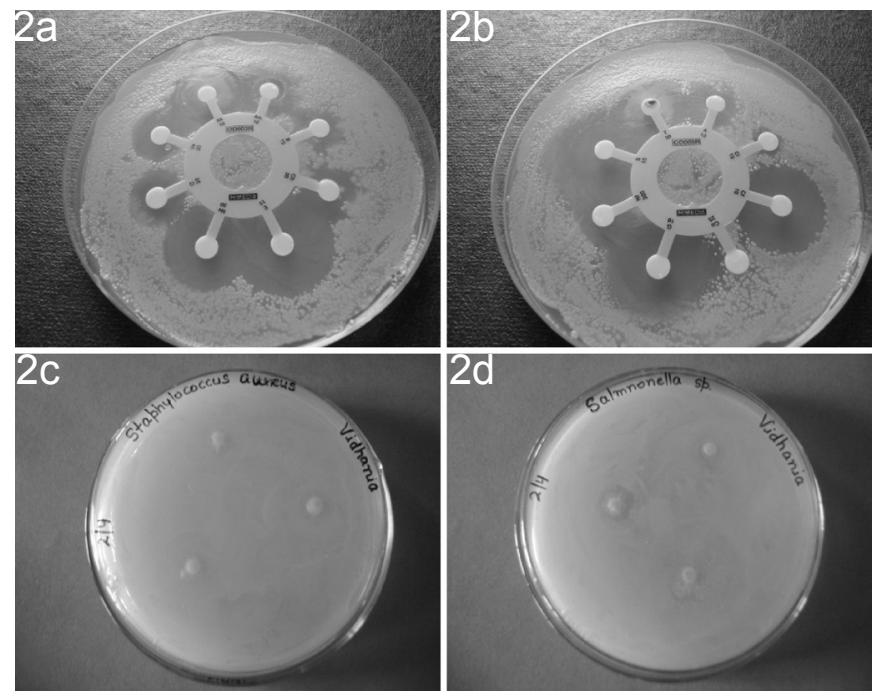

Figure 2 - Growth inhibition by Probiotics (Aquapro ${ }^{\mathrm{TM}}$ ) antibiotic and Herbal Extracts against Gram positive and Gram -ve fish bacterial pathogens. 2a \& 2b Different antibiotics (OD003R and G-I-minus OD005R) against A. hydrophila; $\mathbf{2 c} \&$ 2d. Widhania somnifera extract against Staphylococcus aureus and Salmonella $s p$.

\section{DISCUSSION}

Antibiotics and chemotherapy have been used to prevent disease outbreaks and control proliferation of pathogens for a long time, causing the emergence of drug-resistant bacteria. Presently, although a good number of antibiotics such as norfloxacin, ciprofloxacin, oxytetracycline, gentamicin, chloramphenicol (Sahoo and Mukherjee, 1997), cefazolin (Zhang et al., 2005) and aztreonam (Zhu et al., 2006) etc. for tetracycline-resistant strains have been proven to be successful in controlling the infection. These have their own disadvantages such as the development of disease-resistant strains; carry over, high cost and dose problems as well as indiscriminate use by aqua farmers. Thus, the overuse of antibiotics and other chemicals needs to be checked and the use of alternative methods should be stressed (Taoka et al., 2006). 
Table 2a - The zone of inhibition (in $\mathrm{cm}$ ) by the respective antibiotics of G-II-plus (OD002R) against fish bacterial pathogens.

\begin{tabular}{|c|c|c|c|c|c|c|c|c|c|c|c|}
\hline \multirow{2}{*}{ Antibiotics } & \multicolumn{11}{|c|}{ Fish bacterial pathogens* } \\
\hline & 1 & 2 & 3 & 4 & 5 & 6 & 7 & 8 & 9 & 10 & 11 \\
\hline Ampicillin & 1.6 & $\mathrm{R}$ & 1.4 & $\mathrm{R}$ & $\mathrm{R}$ & 1.4 & $\mathrm{R}$ & 1.6 & $\mathrm{R}$ & $\mathrm{R}$ & $\mathrm{R}$ \\
\hline Carbenicillin & 2.2 & 2.4 & 2.6 & 2.2 & 2.4 & 2.0 & 2.0 & 3.2 & 2.2 & 2.5 & 2.2 \\
\hline Cephotaxime & 3.1 & 2.4 & 3.0 & 2.4 & 2.4 & 2.4 & 1.9 & 3.3 & 2.4 & 2.4 & 2.6 \\
\hline Chloramphenicol & 1.3 & 3.1 & 2.2 & 2.2 & 3.0 & 3.4 & 2.4 & 3.3 & 3.0 & 3.3 & 1.6 \\
\hline Co-trimazine & $\mathrm{R}$ & $\mathrm{R}$ & 3.2 & $\mathrm{R}$ & $\mathrm{R}$ & $\mathrm{R}$ & 3.2 & $\mathrm{R}$ & $\mathrm{R}$ & $\mathrm{R}$ & 2.6 \\
\hline Gentamicin & 1.6 & 1.8 & 1.6 & 2.0 & 2.6 & 2.0 & 1.6 & 2.2 & 2.2 & 2.8 & 1.8 \\
\hline Norfloxacin & 3.6 & 2.8 & 2.8 & 2.8 & 2.8 & 3.2 & 3.4 & 3.4 & 3.0 & 3.2 & 2.8 \\
\hline Oxacillin & $\mathrm{R}$ & $\mathrm{R}$ & $\mathrm{R}$ & $\mathrm{R}$ & $\mathrm{R}$ & $\mathrm{R}$ & $\mathrm{R}$ & $\mathrm{R}$ & $\mathrm{R}$ & $\mathrm{R}$ & $\mathrm{R}$ \\
\hline
\end{tabular}

Table $2 \mathrm{~b}$ - The of zone of inhibition (in $\mathrm{cm}$ ) by the respective antibiotics of G-III-plus (OD003R) against fish bacterial pathogens.

\begin{tabular}{|c|c|c|c|c|c|c|c|c|c|c|c|}
\hline \multirow{2}{*}{ Antibiotic(s) } & \multicolumn{11}{|c|}{ Fish bacterial pathogens* } \\
\hline & 1 & 2 & 3 & 4 & 5 & 6 & 7 & 8 & 9 & 10 & 11 \\
\hline Amikacin & 2.4 & 2.2 & 2.4 & 2.4 & 2.2 & 2.4 & 2.0 & 2.2 & 2.4 & 1.1 & 2.4 \\
\hline Amoxycillin & 1.6 & 1.1 & 1.6 & 1.6 & $\mathrm{R}$ & $\mathrm{R}$ & 1.2 & 1.2 & $\mathrm{R}$ & 2.4 & 1.4 \\
\hline Bacitracin & $\mathrm{R}$ & $\mathrm{R}$ & $\mathrm{R}$ & $\mathrm{R}$ & $\mathrm{R}$ & 1.4 & $\mathrm{R}$ & $\mathrm{R}$ & $\mathrm{R}$ & $\mathrm{R}$ & $\mathrm{R}$ \\
\hline Cephalothin & $\mathrm{R}$ & 1.6 & $\mathrm{R}$ & $\mathrm{R}$ & $\mathrm{R}$ & 1.9 & $\mathrm{R}$ & $\mathrm{R}$ & 1.4 & $\mathrm{R}$ & $\mathrm{R}$ \\
\hline Erythromycin & $\mathrm{R}$ & $\mathrm{R}$ & $\mathrm{R}$ & $\mathrm{R}$ & 3.0 & $\mathrm{R}$ & $\mathrm{R}$ & $\mathrm{R}$ & 2.8 & 2.6 & $\mathrm{R}$ \\
\hline Novobiocin & 1.2 & 1.8 & $\mathrm{R}$ & $\mathrm{R}$ & 2.4 & 2.2 & 1.4 & 1.4 & 2.2 & 2.2 & $\mathrm{R}$ \\
\hline Oxyteracyclin & 1.2 & 1.8 & $\mathrm{R}$ & 1.8 & 2.0 & $\mathrm{R}$ & 1.8 & 1.4 & 1.6 & 1.3 & $\mathrm{R}$ \\
\hline Vancomycin & $\mathrm{R}$ & $\mathrm{R}$ & $\mathrm{R}$ & $\mathrm{R}$ & $\mathrm{R}$ & 2.2 & $\mathrm{R}$ & $\mathrm{R}$ & 1.8 & 2.2 & $\mathrm{R}$ \\
\hline
\end{tabular}

Table 2c - The zone of inhibition (in $\mathrm{cm}$ ) reported for the respective antibiotics of G-I-minus (OD005R) against fish bacterial pathogens.

\begin{tabular}{|c|c|c|c|c|c|c|c|c|c|c|c|}
\hline \multirow{2}{*}{ Antibiotics } & \multicolumn{11}{|c|}{ Fish bacterial pathogens* } \\
\hline & 1 & 2 & 3 & 4 & 5 & 6 & 7 & 8 & 9 & 10 & 11 \\
\hline Ampicillin & $\mathrm{R}$ & $\mathrm{R}$ & 1.1 & 1.2 & 1.9 & $\mathrm{R}$ & $\mathrm{R}$ & $\mathrm{R}$ & 1.4 & $\mathrm{R}$ & $\mathrm{R}$ \\
\hline Ciprofloxacin & 3.2 & 3.4 & 3.0 & 3.0 & 3.1 & 2.8 & 3.1 & 3.0 & 2.8 & 3.5 & 2.4 \\
\hline Colistin & $\mathrm{R}$ & $\mathrm{R}$ & $\mathrm{R}$ & $\mathrm{R}$ & 1.1 & $\mathrm{R}$ & $\mathrm{R}$ & 1.2 & $\mathrm{R}$ & $\mathrm{R}$ & 1.5 \\
\hline Co-trimoxazole & 2.8 & $\mathrm{R}$ & $\mathrm{R}$ & $\mathrm{R}$ & $\mathrm{R}$ & $\mathrm{R}$ & 2.8 & 2.8 & $\mathrm{R}$ & $\mathrm{R}$ & 1.8 \\
\hline Gentamicin & 1.8 & 2.6 & 2.4 & 2.2 & 2.8 & 2.0 & 1.8 & 1.8 & 1.8 & 2.4 & 1.8 \\
\hline Nitrofurantoin & $\mathrm{R}$ & $\mathrm{R}$ & 1.8 & $\mathrm{R}$ & 1.5 & 1.6 & $\mathrm{R}$ & $\mathrm{R}$ & 1.2 & $\mathrm{R}$ & $\mathrm{R}$ \\
\hline Streptomycin & 2.3 & 2.6 & 3.2 & 2.8 & 3.6 & 3.4 & 2.2 & 2.6 & 2.6 & 2.8 & 2.0 \\
\hline Tetracycline & 1.8 & 1.8 & 2.6 & 2.0 & 2.6 & 1.8 & 1.8 & 2.0 & 2.0 & 2.2 & 1.4 \\
\hline
\end{tabular}


Table $2 \mathrm{~d}$ - The zone of inhibition (in $\mathrm{cm}$ ) by the respective antibiotics of G-XVIII-minus (OD057R) against fish bacterial pathogens.

\begin{tabular}{|c|c|c|c|c|c|c|c|c|c|c|c|}
\hline \multirow{2}{*}{ Antibiotic(s) } & \multicolumn{11}{|c|}{ Fish bacterial pathogens* } \\
\hline & 1 & 2 & 3 & 4 & 5 & 6 & 7 & 8 & 9 & 10 & 11 \\
\hline Ceftazidime & 3.0 & 2.6 & $\mathrm{R}$ & 1.2 & $\mathrm{R}$ & $\mathrm{R}$ & 3.0 & 2.4 & $\mathrm{R}$ & $\mathrm{R}$ & 2.6 \\
\hline Ciprofloxacin & 3.8 & 3.6 & 3.0 & 3.2 & 3.0 & 3.2 & 3.6 & 2.2 & 3.2 & 3.2 & 2.8 \\
\hline Cephotaxime & 3.6 & 3.2 & 2.6 & 3.0 & 2.8 & 2.6 & 3.2 & 2.8 & 2.4 & 2.8 & 2.8 \\
\hline Nalidixicic acid & 2.8 & 2.0 & 2.4 & 2.4 & $\mathrm{R}$ & 2.2 & 2.6 & 2.4 & 2.0 & 1.5 & 1.9 \\
\hline Nitrofurantoin & 1.3 & 1.4 & 1.8 & 1.4 & 1.4 & 1.4 & 1.2 & $\mathrm{R}$ & 1.4 & $\mathrm{R}$ & $\mathrm{R}$ \\
\hline Norfloxacin & 3.0 & 3.6 & 3.0 & 3.4 & 2.8 & 3.2 & 2.6 & 2.8 & 3.0 & 3.2 & 2.8 \\
\hline Netillin & 1.8 & 2.6 & 2.0 & 1.8 & 2.4 & 1.6 & 1.8 & 1.8 & 2.2 & 2.4 & 2.0 \\
\hline Ofloxicin & 2.0 & 3.0 & 2.8 & 3.3 & 2.4 & 2.8 & 3.2 & 3.0 & 3.0 & 3.0 & 2.3 \\
\hline
\end{tabular}

*(Table 2a-2d) indicates fish bacterial pathogens: 1-A. hydrophila; 2-Cellobiococcus $\mathrm{sp} . ;$ 3-E. aerogenes; 4-E. cloacae; 5-K. pneumonia; 6-Salmonella sp.; 7-Shigella sp.; 8-Streptobacillus sp.; 9-Streptococcus sp.; 10-P. fluorescens; 11-S. aureus, R-Resistance. The antibiotics giving zone in range 0-1.4 cm were resistant, $\mathbf{1 . 4 - 2 . 0} \mathrm{cm}$ were intermediate and $2.1 \mathrm{~cm}$ or above were sensitive

Table 2e - The zone of inhibition by the constituent antibiotics of Pseudo (OD008R) specific for Pseudomonas fuorescens.

\begin{tabular}{lc}
\hline Antibiotic(s) & Pseudomonas \\
\hline Amikacin & 2.1 \\
Carbenicillin & 2.5 \\
Chloramphenicol & in cm) \\
Ciprofloxacin & 2.1 \\
Cephotaxime & 3.2 \\
Gentamicin & 1.3 \\
Norfloxacin & 2.2 \\
Tobramycin & 3.2 \\
\hline
\end{tabular}

In this study, the sensitivity of eleven pathogens viz. A. hydrophila, Cellobiococcus sp., E. aerogenes, E. cloacae, K. pneumoniae, Salmonella sp., Shigella sp., Streptobacillus sp., Streptococcus sp., P. fluorescens, S. aureus, was checked against different antibiotics. Ciprofloxacin, norfloxacin, cephotaxime, ofloxicin and streptomycin possessed effective inhibition against bacterial growth. The zone of inhibition in range of 3.0-3.8 cm was observed for. P. fluorescens, $S$. aureus, Salmonella sp. E. aerogenes and A. hydrophila and these were sensitive to ciprofloxacin whereas $A$. hydrophila, Cellobiococcus sp., Acetinobactor sp. and Salmonella sp. were sensitive to norfloxacin whereas streptomycin was found highly effective against $E$. cloacae and Cellobiococcus. Most of the bacterial species were resistant to nitrofurantoin, amoxycillin, bacitracin, cephalothin, erythromycin, novobiocin, vancomycin, ampicillin, oxacillin and colistin. Amabile et al., (1995) also observed zone of inhibition in range less than $1.4 \mathrm{~cm}$ for these antibiotics. But there has been risk of using antibiotics as control agents in fish farming due to spread of antibiotic resistance to fish pathogens. (Austin et al., 1995; Moriarty, 1998). Therefore, different researchers suggested the alternative to the non-pathogenic strains of bacteria in the form of probiotics can be applied in fish disease prevention and control.

The safe alternative to antibiotics i.e. commercial preparation of probiotics (Aquapro ${ }^{\mathrm{TM}}$, Exide ${ }^{\mathrm{TM}}$ ) and single probiotics (L. sporogenes, S. boularidia, Rhodococcus sp., Nitrosomonas sp.and $A$. oryzae) were used to study their antagonistic behaviour against the various fish pathogenic isolates. Fuller (1989) reported that probiotic preparations may be made up of a single strain or may contain mixture up to eight strains. The advantage of multiple strain preparations is that they have more sensitivity towards pathogens and active against different aquaculture animals. The probiotic preparation includes a combination of bacterial strains viz. Lactobacillus bulgaricus, Lactobacillus plantarum, Streptococcus thermophillus, Enterococcus faecium, Enterococcus faecalis, Bifidobacterium sp. and Escherichia coli. Venkatesan et al. (2012) isolated probiotic organisms, Bifidobacterium sp., Lactobacillus sp. and S. cerevisiae from soil, curd and yeast pellets and was that Bifidobacterium $\mathrm{sp}$. had the high inhibitory effect against Salmonella sp supporting that single probiotics are also effective against bacterial pathogens.

In the present study we have reported that Aquapro ${ }^{\mathrm{TM}}$ and Exide $^{\mathrm{TM}}$, both are mixture of micro-organisms, gave better zone of inhibition in comparison to individual probiotic strains. A minimum effective dose $(10 \mu l)$ of Aquapro ${ }^{\mathrm{TM}}$ was sufficient to inhibit the growth of Gram positive (Cellobiococcus sp. and S.aureus) and Gram negative (P. fluorescens and E. aerogenes) bacteria. Even a little dose of about $5 \mu 1$ was sufficient to inhibit the growth of $A$. hydrophila. In $L$. sporogenes the maximum value of zone of inhibition observed was $1.133 \mathrm{~cm}$ against A. hydrophila and the minimum zone $0.667 \mathrm{~cm}$, was against $K$. pneumoneae which are lesser as compared 
to the zone of inhibition given by multiple strain probiotic. Similarly Dahiya et al. (2012) reported the efficacy of three probiotics single as well as in mixture, namely Lactobacillus sporogenes, Saccharomyces boulardii and and a mixed probiotc (Nitromonas, Rhodococcus, Bacilus megaterium, Lecheni formis, Desulphovibrio sulphuricum, Psuedomonas, Chromatium, Chlorobium, Thiobacillus, Thioxidants, Thiobacilus ferroxidant, Methylomonas methyanica, Glucon acetobactor, Azospirillum, Trichoderma, Shizophyllum commune and Sclertium gluconicum) against the pathogenic Micrococcus sp. and found that all these probiotics were very effective against the bacterium.

Austin et al. (1995) also observed a similar phenomenon and used $V$. alginolyticus as a probiotic strain to reduced the diseases caused by $A$. solmonicida, V. anguillarum and V.ordalli in P. monodon. Brunt et al. (2007) reported the effectiveness of Bacillus sp. and A. sobria as probiotics, recovered from the digestive tract of rainbow trout, Oncorhynchus mykiss and ghost carp, Cyprinus sp., respectively for the control of infections caused by A. salmonicida, Lactococcus garvieae, Streptococcus iniae, Vibrio anguillarum, Vibrio ordalii and Yersinia ruckeri. Lim et al. (2011) isolated probiotic bacteria OY15 from oysters and scallops which inhibited the growth of known scallop-pathogen bacterial strains B183 and B122 and found that it can also be incorporated into functional foods for use in shellfish hatcheries which willsignificantly improve larval survival.

The second alternative to antibiotics along with probiotics is the use of herbal medicines for disease cure in human as well as animals. In the last 20 years research conducted on the natural materials as a source of new antibacterial agents. Different extracts from traditional medicinal plants have been tested. Many reports show the effectiveness of traditional herbs against microorganisms. As a result plants are one of the bedrocks for modern medicine to attain new principles (Evans et al., 2002). In the present study, four herbal plants viz $A$. indica, $A$. barbadensis, $W$. somnifera and $M$. charantia, were screened for anti-bacterial activity against the fish bacterial pathogens. An inhibition was observed for all the four plants. However, $W$. somnifera extract was used in combination with probiotic (L. sporogenes), the zone of inhibition was less as compared to the individual herbal samples of $W$. somnifera. Similarly Balakrishnan et al. (2006) studied the anti-bacterial activity of Mimosa pudica, Aegle marmelos, Withania somnifera and Sida cordifolia against Bacillus subtilis, S. aureus, Kl.ebsiella pneumoniae, P. aeruginosa, Escherichia coli and Salmonella typhi and maximum inhibitory zone was observed in W. somnifera against Bacillus subtilis (35mm) and Salmonella typhi (26 mm).

\section{CONCLUSION}

The antibiotic compounds although potent against various pathogenic organisms in medicine but in aquaculture, different studies indicated the chances of development of antibiotic resistance among the fish pathogens. Keeping this in view, the probiotics (with single and multiple strains of non-pathogenic bacteria and / fungi), plant extracts, different oils, and more potent the bacteriophage therapy can be used to control fish pathogens. In this study, we have used probiotics and plant based extracts to check their effectiveness and antimicrobial potency against the eleven fish pathogens and results validated through statistical analysis. However, further in vitro as well as in vivo studies need to be conducted to know more specifically about the effect and doses of these compounds that prove to be used in fish farming and management.

\section{ACKNOWLEDGEMENT}

The authors wish to thank reviewers for critical suggestions that have improvement this manuscript.

\section{REFERENCES}

ABUTBUL, S., GOLAN, G.A., BARAZ NANI, O., OFIR, R. \& ZILBERG, D. 2005. Screening of desert plants for use against bacterial pathogens in fish . Israeli J. Aquacult. Bamidgeh. 57: 71-80.

AHILAN, D.H., SALMINE, S. \& LILIUS, E.M. 2004. Innate immune responses in rainbow trout (Oncorhynchus mykiss, Walbaum) induced by probiotics. Fish Shellfish Immunol. 21: 513-24. http://dx.doi.org/10.1016/j.fsi.2006.02.007

ALI, A., 2000., Probiotic in fish farming-Evaluation of a candidate bacterial mixture. Sveriges Lantbruks, Universitet. Umea, Senegal.

AUBIN, S. K., PANIGRAHI, A., KIRON,V., PUANGKAEW, J., KOBAYASHI, T., SATOH, S. \& SUKITA, H. 2005., The viability of probiotic bacteria as a factor infuencing the immune response in rainbow trout. Oncorhynchus Mykiss. Aquacult.243: 241-254. http://dx.doi.org/10.1016/j.aquaculture.2004.09.032

AUSTIN, B., STUCKEY, L.E., ROBERTSON, P.A.W., EFFENDI, I. \& GRIFFITH, D.R.W.1995. A probiotic strain of Vibrio alginolyticus effective in reducing disease caused by Aeromonas salmonicida, Vibrio anguillarum and Vibrio ordalli. J. Fish Dis. 18: 93-96. http://dx.doi.org/10.1111/j.1365-2761.1995. tb01271.x

BALAKRISHAN, N., BHASKAR, V., JAYAKAR, B. \& SANGAMESWARAN, B.2006. Antibacterial activity of Mimosa pudica, Aegle marmelos and Seda cordifolia. Short communication. Pharmocognosy Magzine. 2(7): 198-199.

BANERJEE, R., MISRA, C.K., DAS, B.K., MUKHERJEE, S.C. \& MEHER, P.K.2007. The immunomodulatory effects of tuftsin on the non-specific immune system of Indian major carp, Labeo rohita. Fish Shellfish Immunol. 20: 728-738. http://dx.doi. org/10.1016/j.fsi.2005.09.004

BONDAD-REANTASO, M. G., SUBASINGHE, R. P., ARTHUR, J. R., OGAWA, K., CHINABUT, S., ADLARD, R., TAN, Z. \& SHARIFF, M. 2005. Disease and health management in Asian aquaculture. Vet. Parasitol. 132: 249-272. http://dx.doi. org/10.1016/j.vetpar.2005.07.005

BRUNT, J., NEWAJ-FYZUL, A. \& AUSTIN, B. 2007. The development of probiotics for the control of multiple bacterial diseases of rainbow trout, Oncorhynchus mykiss. Fish Physiol. Biochem. 18: 241-252. http://dx.doi.org/10.1111/j.13652761.2007.00836.x

BULLOCK, G.L. \& STUCKEY, H.M. 1975. Aeromonas salmonicide detection of asymptomatic infected trout. Prog. Fish Culturist. 37:237-239. http://dx.doi.org/10.1577/1548- 
8659(1975)37[237:AS]2.0.CO;2

Dahiya T., Gahalawat S.K. \& Sihag R.C. (2012). Elimination of Pathogenic Bacterium (Micrococcus sp.) by the Use of Probiotics. Turkish J. Fish. Aquatic Sci. 12: 185-187. http:// dx.doi.org/10.4194/1303-2712-v12_1_21

EVANS, C.E., BANSO, A. \& SAMUEL, O.A. 2002. Efficacy of some nupe medicinal plants against Salmonella typhi: an in vitro study. J. Ethnopharmacol. 80: 21-24. http://dx.doi.org/10.1016/ S0378-8741(01)00378-6

FAZELI, L.F. \& TAMAKI, O. 2006. Control of saprolegniosis in the eel Anguilla australis Richardson, by Aeromonas media strain A199. Aquacult. 240: 19-27. http://dx.doi.org/10.1016/j. aquaculture.2004.04.009

FULLER, R. 1989. Probiotics in man and animals - A review. J. Appl. Bacteriol. 66: 365-378.

GHOS, S., KUMAR, R., MUKHERJEE, S.C., PRASAD, K.P., PAL \& A.K.1999. Evaluation of Bacillus subtilis as a probiotic to Indian major carp Labeo rohita (Ham.). Aqua. Res. 37: 1215-21. http://dx.doi.org/10.1111/j.1365-2109.2006.01551.x

GRAM, L., MELCHIORSEN, J., SPANGGAARD, B., HUBER, I. \& NIELSEN, T. F.2004. Inhibition of Vibrio anguillarum by Pseudomonas fluorescens AH2, a possible probiotic treatment of fish. Appl. Environ. Microbiol. 65:969-973.

HENDRY, C.I., VAN STAPPEN, G., WILLE, M., \& SORGELOOS, P. 2001. Larvi'01 - Fish \& Shellfish Larviculture Symposium, European Aquaculture Society, Special publication $N^{\circ} 30$, Oostende, Belgium, 30:37-39.

KANNAPPAN S \& KRISHNAMOORTHY K. 2013. Extraction and detection of quorum sensing $\mathrm{N}$ - acyl homoserine lactones from shrimp pathogen Vibrio harveyi and antagonistic effect of terrestrial plants against its growth. African J. Microbial. Res. 7(26):3275-84. http://dx.doi.org/10.5897/AJMR2013.5562

LI H., RUAN J. \& DURBIN R. 2008. Mapping short DNA sequencing reads and calling variants using mapping quality scores. Genome Res. 18:1851-1858. http://dx.doi.org/10.1101/gr.078212.108

LIM H. J., KAPAREIKO D.,SCHOTT E.J., HANIF A. \& WIKFORS G. H.2011. Isolation and Evaluation of New Probiotic Bacteria for use in Shellfish Hatcheries: I. Isolation and Screening for Bioactivity. J. Shellfish Res. 30(3):609-615. http://dx.doi. org/10.2983/035.030.0303

LUNDEN, T., MIETINEN S., LONNSTROM L.G., LILIUS, E.M. \& BYLUND, G.1998. Influence of oxytetracycline and oxolinic acid on the immune response of rainbowtrout. Fish Shellfish Immunol. 9(3): 204-212. http://dx.doi.org/10.1006/ fsim. 1998.0142

MORIARTY, D. 1998. Control of luminous Vibrio species in penaeid aquaculture ponds. Aquaculture 164:351-358. (Oncorhynchus my-kiss). Fish Shellfish Immunol. 8: 217-230. http://dx.doi. org/10.1016/S0044-8486(98)00199-9

ONARHEIM AM, WIIK R, BRUGHARDT J \& STACKEBRANDT E 1994. Characterization and identification of two Vibrio species indigenous to the intestine of fish in cold sea water, description of Vibrio iliopiscurius sp. nov. Syst. App. Microbio. 17: 370-379.
PANDEY G., SHARMA M., MANDLOI A.K. \& SHANI Y.P. 2012. Antimicrobial activity of some medicinal plants against fish pathogens. Int. Res. J. Pharmacy. 3(4):28-30.

PATIL, R., JAYASEKARAN, G., SHANMUGN, RA \& JEYA SHAKILA R.2001. Control of bacterial pathogens, associated with fish disease, by antagnostic marine actinomycetes isolated from marine sediments. Indian J. Mar. Sci. 30(4):264-267.

ROLLO, G.K., EL-SERSY, N.A., ABDEL-RAZEK, F.A. \& TAHA, S.M. 2006. Evaluation of various probiotic bacteria for the survival of Penaeus japonicus larvae. Fresenius Environ. Bull. 15: 1506-1511.

TAOKA C. S. \& LLOYD S.W. 2006. Evaluation of a commercial bacterial ammendment for improving water quality in channel catfish ponds. Research report no. 10, p. 1-4. Mississippi Agricultural and Forestry Experiment Station, Mississippi State University.

SAHOO, P.K. \& MUKHERJEE, S.C. 1997. In-vitro susceptibility of three bacterial pathogens of catfish to 23 antimicrobial agents. Indian J. Fisheries. 44: 393-397.

SAKATA, T.1990. Microflora in the digestive tract of fish and shellfish. In: Microbiology in Poecilotherms. Lesel R (Ed) Elsevier. Amsterdam.

Shankar, M., \& Kiran, B.R. 2013. Review On Usage Of Medicinal Plants In Fish Diseases. Int. J. Pharm. Bio. Sci. 4(3): (B) 975 986.

SRINIVASAN,P. \&RAMASAMY, P. 2009. Occurrence, distribution and antibiotic resistance patterns of Vibrio species associated with viral diseased shrimp of south Indian Aquaculture environment. Int. J. Agrl. Sci. 1(2):1-10.

SUBASINGHE, R.P., 2005. Epidemiologic al approach to aquatic animal health management: opportunities and challenges for developing countries to increase aquatic production through aquaculture. Prev. Vet. Med. 67: 117- 124. http://dx.doi. org/10.1016/j.prevetmed.2004.11.004

VENKATESAN S., KIRITHIKA M., ROSELIN I., GANESAN R. \& MUTHUCHELIAN K. 2012. Comparative invitro and invivo study of three probiotics organisms,Bifidobacterium sp., Lactobacillus sp., S. cerevisiae and analyzing its improvement with the supplementation of probiotics. Int. J. Plant. Animal Enviorn. Sci. 2(2): 94-106.

VERSCHUERE L., ROMBAUT G., SORGELOOS P. \& VERSTRAETE W. 2000. Probiotic Bacteria as Biological Control Agents in Aquaculture. Microbiol. Mol. Biol. Rev. 64(4): 655-671. http://dx.doi.org/10.1128/MMBR.64.4.655-671.2000

ZHANG, X.J., FANG, H., CHEN, C.Z., GE, M.X. \& WANG, X.Y.2005. Sensitivity of pathogenic Edwardsiella tarda isolated from flounder (Paralichthys olivaceus) to some antimicrobial agents. Fish. Sci. 24: 15-18.

ZHU, Z.C., SHI, X.G., ZHANG, S.J., JIANG, G.J., XING, Z.B., ZHAO, Y.L., LI, Z.J. \& WU, P. 2006. The pathogenic bacteria of the ascites in Japanese flounder (Paralichthys olivaceus). Fish. Sci. 7: 325-329. 